\title{
Baudelaire en el Perú
}

\author{
POR Estuardo NúÑEZ
}

El Instituto de Literatura de la Facultad de Letras ha auspiciado cálidamente la iniciativa de ofrecer este Homenaje a la memo. ria de una de las más deslumbrantes figuras de la poesía francesa moderna, no sólo por el contenido humanístico que entraña toda celebración de esta índole, sino por que la obra de Carlos Baudelaire ha tenido especial resonancia en el proceso de la literatura peruana.

Celebraciones de este jaez tienen la virtud de actualizar los aspectos latentes o polémicos de una obra o de una figura y de establecer la coordenadas de su proyección en el futuro y sobre todo, de propiciar, luera de su ámbito estrictamente nacional o europeo, las investigaciones de tipo comparatista, que no se sustentan solamente en la exégesis de tipo ponderativo o monumental, sino en la rigorośaconfrontación dé datos len orden a la asimilación de sus aportes, el traslado de una lengua a otra de sus expresiones, su acción adoctrinante, su influjo ostensible u oculto, su difusión espacial y su perduración temporal.

1857 fue sin duda año crucial en que periclitaba una concepción del arte literario, desprestigiada por la degeneración del romanticismo, advertible en el desborde sentimental, en la exageración de la poesía confidencial, en una lírica descriptiva y adocenada, en las formas de la elocuencia bastarda, en la ausencia del rigor de forma y de selección estética. Pero en ese año nacía, con Las Flores del Mal de Baudelaire, un nuevo sentido de la poesía, la reivindicación de la palabra, una técnica depurada en la elaboración de las imágenes y un rigor estético de composición - que habría de tener proyección futura incalculable. Un contenido de nueva creación y de angustiosa originalidad, emergía de sus estrofas penetradas de tragedia íntima y de nuevos mirajes de la 
naturaleza. Sus poemas, entre ellos "Correspondencias", contenían un mensaje de estética novadora, que habrían de asimilar por igual "parnasianos" y "simbolistas". El soneto "Correspondencias", porta en potencia toda la teoría sinestésica que aunque inconcientemente practicada por los grandes exponentes de la poesía universal desde el Renacimiento - como Góngora y Camoensy luego por algunos del romanticismo como el propio Hugo y también Heine, resulta concientemente desarrollada por parnasianos y simbolistas de la segunda mitad del XIX. El famoso soneto de Las Vocales de Rimbaud y las formulaciones estéticas y técnicas de Mallarmé - el inconmensurable y siempre admirable promotor de toda la nueva poesía hasta nuestro tiempo - tomaron su origen en la teoría de la imagen poética esbozada por Baudelaire. Un nuevo mundo de realizaciones tenía a su disposición el poeta, nuevo traumaturgo, para combinar en sus imágenes sensaciones desajustadas de su normal producción en la naturaleza. La audición coloreada o la visualidad audible o multitud de otras combinaciones de sensaciones provenientes de todos los sentidos se reunían como diría el propio Baudelaire en "una metamorfosis mística de todos mis sentidos fundidos en una solo".

Una nueva concepción de la palabra se inaugura. Si para el lenguaje común, la palabra sigue siendo expresión de la cosa o de la idea, ese valor - significación- se trasforma o se adiciona en el poeta, de un valor sugerencial, gracias al juego de combinaciones que el arte hace posible con sonidos y sensaciones inesperadas que brotan de las palabras. Todo ello puldo ser vislumbrado por los grandes exponentes de la poesía anterior, pero sólo empieza a adquirir una sugestiva formulación y un culto intensivo a partir de Baudelaire. Por ello podría afirmarse que hemos llegado a la apertura de una nueva compuerta en el mundo de la poesía, por donde va a desembocar una nueva corriente de realizaciones artísticas que significarán a la larga la transformación del arte de la poesía. Su obra es un esfuerzo genial para desembarazar la poesía de todo ornamente vano y para alcanzar el ideal de la poesía pura al cabo de los años.

Baudelaire no tuvo eco inmediato en América; ese eco fue tardío pero fue sustantivo. Buscando sus huellas en el Perú, hemos hallado sus primeras resonancias a partir de 1890. Los románticos que viajaron a Europa por la época de la publicación de Las flores del $M a l$ o después, no llegaron a captarlo. Ni Palma, ni Althaus, 
ni Salaverry, ni Llona, ni Márquez acogen nada de él y se explica el fenómeno por el deslumbramiento que opera sobre ellos, la exaltación de los valores consagrados del Romanticismo europeo: Hugo, Byron, Heine o Leopardi, para no mencionar sino a los representativos poetas que ejercieron influjo dominante.

A pesar de cuanto se ha dicho acerca del posible influjo de Baudelaire sobre la poesía de Nicanor de la Rocca de Vergalo, -singular exponente de un romanticismo anárquico, un tanto al margen del movimiento generacional peruano-, no he encontrado rastro alguno positivo de tal influjo. Rocca de Vergalo luchó por una reforma poética todavía bajo la tónica de un concepto preceptivo, esto es, que su impulso perseguía sustituír una preceptiva con otra. Su aliento revolucionario era esencialmente formalista y para nada incidió en la reforma de la idea poética, de la concepción de la imagen y de la metáfora o del sentido profundo de la poesía. Era la suya una reforma si se quiere retórica y por lo tanto referida únicamente a la poética. La estructura y la esencia de la poesía estaban completamente al margen de su pensamiento. Por más que su obra se produjo después de la publicación de Las Flores del Mal, o sea en el decenio del 60 al 80, sus predilecciones siguieron siendo los grandes penates del romanticismo como Víctor Hugo, o algunos representantes del parnasianismo más conservador como Teodoro de Banville, I. Soulary y Armand Silvestre. En náda entraron en sus concepciones las tendencias que inauguraba Baudelaire que pueden resumirse encel taterio de la "depuración" del sentido poético, en el misterio de los conflictos íntimos o en la angustia de la búsqueda de combinaciones de fenómenos sicológicos que desembocan en una expresión poética cargada de significaciones múltiples y llena de infinitas sugerencias. Rocca de Vergalo con su poesía sentimental, ingenua, simple y muchas veces de dudoso gusto y de gastados efectos, estuvo siempre a una distancia sideral de aquellos aportes del estro "baudelairiano".

La primera huella de Baudelaire en el Perú la hemos hallado en la versión del poema "La musa enferma", publicada en Arequipa en 1892 y que tradujo Edilberto Zegarra Ballón (1). De 1893 ○ 90 es un Grafito de Manuel González Prada, escrito durante

(1) 'E. Zegarra Ballón, traducción de "La Musa enferma", publicada en El Cosmos, No 1, Arequipa, Perú, junio de 1892. 
su residencia en París (2) y en que está reflejada la admiración por su obra y la impresión de una lectura detenida de Las Flores del Mal :

(Baudelaire)

En la extraña poesía de su cerebro macabro ¡Qué florescencia de ritmos! !Qué precisión de vocablos!

Se revuelca en la carroña $Y$ se sumerge en el fango; Mas resurge oliendo a mirra, Con una perla en la mano.

Pero una huella más delicada, de su fervor por Baudelaire se encuentra en su poema "En país extraño", incorporado a su libro Exóticas (Lima, 1911), aunque escrito seguramente años atrás; en dicho poema se insertan como epígrafe estos versos de Baudelaire:

métamorphose mystique de tous mes sens fondus en un!

que Prada traduce y desarrolla en su propio poema:

Yo camino bajo un cielo, No esplendor ni oscuridad;

En un país muy remoto, No vivido ni real.

Donde se oye con los ojos

Donde se ve con palpar y se funden los sentidos en misteriosa unidad.

Saboreo luz, y gozo

La esquisita voluptad

(2) M. González Prada, Grafitos, Tip. L. Bellenand et fils, Paris, 1937. 
de las músicas azules

y del olor musical

¿Soy la parte o soy el todo?

No consigo deslindar

Si yo respiro en las cosas

O en mí las cosas están. (3).

Estas estrofas se impregnan profundamente de la concepción "baudelairiana" de la poesía y no sólo se inspiran y en parte traducen el poema del epígrafe, sino que denotan la asimilación del soneto "Correspondencias".

En los dos primeros decenios del presente siglo es síntoma del culto por Baudelaire la constante y frecuente publicación de traducciones de sus poemas en revistas y periódicos de gran difusión pública. Prisma, Actualidades, Contemporáneos, Balnearios, Colónida, Cultura, El Perú, Variedades, etc., (4) recogen comentarios e informaciones sobre el poeta a la vez que versiones de sus estrofas. El ambiente espiritual era en esos años años propicio a Baudelaire. No comparto sin embargo del juicio de Riva Agüero que cree advertir un influjo decisivo del poeta francés sobre Enrique Bustamante y Ballivián más próximo sin duada a Theophile. Gautier $\mathrm{u}$ otros parnasianos proclives a las notas de cortesanía, ni tampoco participo del parecer de Luis Monguio cuando señala "baudelairismo" en la poesía de Alberto Ureta, principalmente'en su libro Rumor de Almas (1911). En Ureta la predilección parece estar más bien en Samaín, si cupiera hablar en su obra de alguna influencia francesa aparte de su lastre oriental de Khayam y de ciertos motivos bíblicos. Algún eco "baudelairiano" parece emerger de la lírica breve de Ventura García Calderón, José Lora y Lora y Enrique A. Carrillo, desde antes de 1910.

Si hablamos de traductores tenemos que referirnos en este lapso a Domingo del Prado que publica en 1900 la versión del prólogo

(3) M. González Prada, Exóticas, Lima, Tip. El Lucero, 1911.

(4) Véase Prisma de Lima, No 20 y 24 Enero de 1907, Balnearios de Barranco (Lima) No 221, 29 de agosto 1915, Colónida, Nos. 3 y 4,- Lima, 1916, El Perú, No 227, 18 de marzo de 1917; Variedades, No 760, 23 de Setiembre de 1922. 
de Las flores del Mal (5) y a Juan Tassara, inquieta vocación literaria desparecida en agraz, y autor de profusas versiones de Baudelaire aparecidas por varios años en el importante y revelador semanario Balnearios (6). A Tassara debemos lo que podría ser una pequeña antología de versiones de Baudelaire, hechas con devoción y con talento interpretativo. Tengo recopilados de Tassara los poemas "Elevación", "Moesta et errabunda", "Tristeza de la luna", "El Albatros".

Pero la más cabal asimilación de Baudelaire se operó sin duda en la obra de José María Eguren, el más original de nuestros poetas anteriores a Vallejo. No cabe hablar aquí propiamente de una influencia directa, sino de una asimilación conciente que extrae el más puro e íntimo mensaje estético. Eguren lo amaba en verdad y lo había leído asídua y fervorosamente. De él había extraído el secreto de las palabras evocadoras, el sistema de la transposición de las sensaciones, la fulminación de lo prosaico, la instauración de un orden poético distinto del orden real. Esto significaba asimilar a Baudelaire en sus esencias. Pero hay algo más que Eguren heredó del francés. El crítico Ferdinand Brunetiere ha precisado una fuerte afinidad artística entre Baudelaire y Richard Wagner, el gran músico y escritor romántico alemón. Tanto el autor de Las flores del Mal, como el de El anillo de los Nibelungos pertenecieron a una época similar: las postrimerías del romanticismo. Baudelaire refuerza su concepción del símbolo artístico en Wagner. Pues bien, la través de Baúdelaire se incuba en el peruano Eguren esa curiosidad por lo que actualiza Wagner de la mitología nórdica. El misterio y el enigma unió almas contemporáneas, como las de Baudelaire y Wagner. Eso mismo captó de ambos seguramente Eguren. De Baudelaire le vino nó el satanismo, pero sí seguramente el sentido de la imagen original y sobria y el uso poético de las palabras tan ascendrado en Eguren.

Si Eguren llegó a la asimilación de Wagner por la acción de Baudelaire, seguramente por tan digno intermediario pudo también operarse la fervorosa admiración por Edgard Allan Poe, en quien Eguren encuentra correlato para su fantasía y su misterio. De Poe y de Baudelaire procede asimismo el culto sugerente de la noche

(5) Véase El modernismo, No 4, Lima, Diciembre de 1900.

(6) Véase Balnearios, Nos. 174,8 de febrero de 1914 , No 175,15 de febrero de 1914; No 158, 26 de abril de 1914. 
y del último, sin duda alguna, la nostalgia de países lejanos y quiméricos, la Germania, la Escandinavia, el Oriente.

En esta época, o sea los dos primeros decenios del siglo $X X$, el temperamento poético más afín a Baudelare fue Manuel Betlroy, inspirado poeta en su juventud $y$ lector devoto de los poetas provenzales y franceses. Sus múltiples sonetos, publicados sobre todo en el semanario Balnearios, denotan la impronta baudelairiana, en la forma depurada de prosaismos y en los temas de sensual fantasía, aunque exentos de la amargura y de la angustia. Si en Eguren se produjo la asimilación de ciertas facetas típicas, incorporadas a una elaboración original, en Beltroy se anotaba la entusiasta adhesión juvenil a los mismos temas y al impulso formal, en un intento interpretativo derivado después a la propia versión de los poemas de Las flores del Mal, en que el esfuerzo de Beltroy, como hemos de ver más adelante, encontró el mejor resultado.

Otro autor peruano de ese momento, Abraham Valdelomar, no fue "baudelairiano" en su obra, pero sí en su actitud personal. Gustaba practicar las excentricidades más detonantes frente a burgueses y provincianos burdos, y sin duda había leído en alguna biografía aquellas frases dichas en comedor lleno de gente y a voz en cuello: "Después de haber asesinado a mi pobre padre..." y seguía contando. O esta interrogación : "¿No ha comido Ud. nunca sesos de niño?". Siguiendo el estilo del maestro, Valdelomar practicó esta "suerféle divertial fecursos" de"notoriedad en las situaciones más inesperadas.

El impacto mayor de Baudelaire se operó de esta suerte sobre la generación reunida en torno de la revista Colónida (1916) que dirigía Valdelomar. La revista cobijó varias traducciones de sus poemas. Después de esa fecha han mantenido el culto de Baudelaire entre otros, Manuel Beltroy y últimamente Raúl Deustua. Pero las versiones de Beltroy que se han venido publicando en los últimos 30 años revelan una identificación ejemplar con el espíritu y la letra del gran poeta francés y no vacilamos en calificarlas como las más acertadas en el mundo americano de habla hispana. Vibra en ellas la intensidad del acento desgarrado, el enigma lírico y el tono musical particular de la poesía de Baudelaire. Los poemas conservan su intensidad y la idea poética mantiene toda su vigencia. Las versiones muestran así cualidades extraordinarias que no se dan con frecuencia en otros traductores americanos o 
españoles que no tienen como Beltroy el conocimiento ilustrado y vivido de la lengua francesa (7).

La perdurable obra de Baudelaire ha dejado un aporte positivo en estas latitudes de América, donde su nombre es paradigma de verdad poética, de selección estética, del culto de la expresión simbólica, y de rigorosa elaboración de la palabra en cuanto vehículo depurado de la expresión literaria que equivale a superación de la palabra elocuente y retórica.

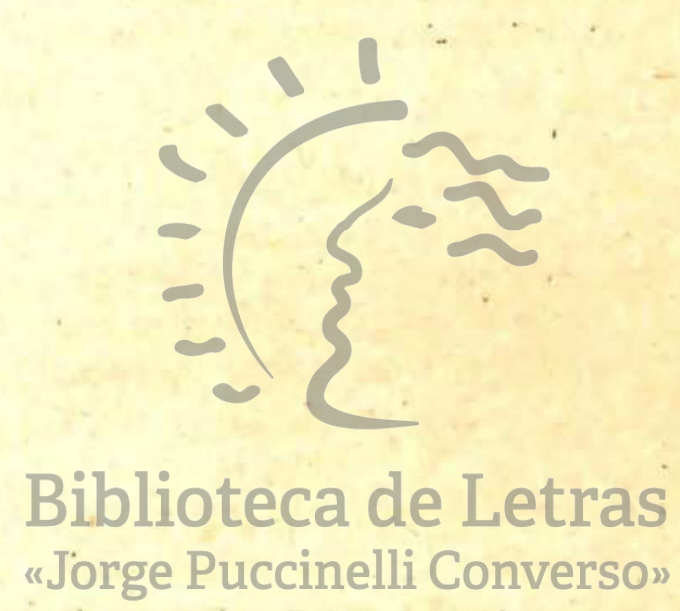

(7) Estas versiones se reunieron en un folleto de Bomenaje a Baudelaire, Departamento de Extensión Cultural de la Universidad Nacional Mayor de San Marcos, Lima, 1957. Es una edición bilingüe de 14 poemas, en versiones de M. Beltroy. 